\title{
Raw materials of cooked ring sausages as a source of spoilage lactic acid bacteria
}

\author{
Mäkelä, P. \\ International Association for Food Protection \\ 1990
}

Journal of food protection. 1990. 53: 965-968.

http://hdl.handle.net/1975/757

Downloaded from Helda, University of Helsinki institutional repository.

This is an electronic reprint of the original article.

This reprint may differ from the original in pagination and typographic detail.

Please cite the original version. 


\title{
Raw Materials of Cooked Ring Sausages as a Source of Spoilage Lactic Acid Bacteria
}

\author{
PIA M. MÄKELÄ ${ }^{1}$, HANNU J. KORKEALA ${ }^{1}$ and JORMA J. LAINE ${ }^{2}$ \\ College of Veterinary Medicine, Department of Food and Environmental Hygiene, P.O. Box 6, SF-00581 Helsinki, Finland; \\ Finnish Meat Research Center, P.O. Box 56, SF-13101 Hämeenlinna, Finland
}

(Received for publication June 7, 1989)

\section{ABSTRACT}

The microbial numbers and the lactic acid bacteria population of the raw materials of cooked ring sausages were studied in order to determine the presence of the spoilage lactic acid bacteria of the sausages. The highest aerobic plate counts and lactic acid bacteria counts (up to the level of $10^{8}$ and $10^{5} \mathrm{CFU} /$ $\mathrm{g}$, respectively) were found in the pork skin emulsion and the meat trimmings. Lactic acid bacteria were also commonly found in the skim milk powder and the potato flour. Lactic acid bacteria isolates able to multiply at $8^{\circ} \mathrm{C}$ were recovered from all the raw materials studied except for the commercial spice mixture. These isolates could be divided into 11 different groups according to their morphological and biochemical characteristics. Isolates resembling the lactic acid bacteria strains responsible for the spoilage of vacuum-packed cooked ring sausages were found in the pork skin emulsion, the meat trimmings, and the potato flour. These raw materials can thus form a source for the spoilage bacteria of the sausages at a sausage processing plant.

Cooked ring sausages are commonly used as a main dish in Finland. The ingredients of the sausages are beef and pork meat, potato flour, skim milk powder, spices, sodium glutamate, phosphates, nitrite, ascorbic acid, and water. The sausages are dried $15-30 \mathrm{~min}$ at $40-60^{\circ} \mathrm{C}$, smoked 20-30 min at $70-75^{\circ} \mathrm{C}$, and cooked $35-40 \mathrm{~min}$ at $74-76^{\circ} \mathrm{C}$.

Lactic acid bacteria are the dominant microorganisms of the population developing on vacuum packed meat products $(1,2,14,16)$. In studies concerning vacuum-packed cooked ring sausages, lactic acid bacteria were similarly found to form the main microbial population $(9,10)$. The numbers of lactic acid bacteria were found to be much higher in the surface layer than at the center of the ring sausages, and these surface bacteria have been shown to be responsible for spoilage $(7,9)$. The surface of the sausages has been shown to become contaminated with lactic acid bacteria during handling following the cooking of the sausages (13). Lactic acid bacteria were also found in the air and on the structural and working surfaces in the chilling and packing rooms of the plants studied, suggesting that these rooms can act as sources of the bacterial contamination (13).
The origin of the spoilage bacteria of cooked sausages at a sausage processing plant has not been studied. There have been some studies concerning the sources of lactic acid bacteria in other meat products. Kitchell and Ingram (6) found that the lactobacilli which predominated on vacuum-packed bacon had originated on the skin of the pigs. Lörincz and Incze (12) isolated Lactobacillus viridescens from raw and processed meats. As the common ingredients of the cooked sausages, meat, spices, and milk powder are known to harbour substantial microbial populations $(4,15,20)$, raw materials form one potential source of spoilage bacteria at a sausage processing plant.

This work was undertaken to study the origin of the spoilage bacteria of vacuum-packed cooked ring sausages. The purpose of the study was to determine whether the raw materials of the sausages could form a source of these bacteria. The microbial population and microbiological quality of the raw materials were therefore studied.

\section{MATERIALS AND METHODS}

\section{Samples}

The raw materials of cooked ring sausages were obtained from a sausage processing plant. The materials studied were pork skin emulsion, pork trimmings, beef trimmings, commercial spice mixture, skim milk powder, and potato flour. The meat trimmings contained $2.6 \% \mathrm{NaCl}$. The materials were sampled on ten visits over a period of five months.

\section{Microbiological analyses}

Twenty-five grams of the sample were homogenized with $225 \mathrm{ml}$ of physiological $\mathrm{NaCl}$ solution. The samples of pork skin emulsion and meat trimmings were examined immediately afterwards, while the samples of spice mixture, skim milk powder, and potato flour were preincubated for $3 \mathrm{~h}$ at $25^{\circ} \mathrm{C}$ to facilitate the repair of injured microorganisms.

The samples were serially diluted 10 -fold in physiological $\mathrm{NaCl}$ solution and plated on APT agar (Difco) for aerobic plate count, and on MRS-S agar (7) for lactic acid bacteria count using spread plate method. The APT plates were incubated aerobically and the MRS-S plates were incubated in an anaerobic jar using an $\mathrm{H}_{2}+\mathrm{CO}_{2}$ gas generating kit (Oxoid), at $20^{\circ} \mathrm{C}$ for $5 \mathrm{~d}$.

A total of 218 bacterial strains were isolated from the MRS$\mathrm{S}$ plates at random. The ability of the isolates to grow at chill 
temperatures was tested on MRS agar (Oxoid) at $8^{\circ} \mathrm{C}$ for $10 \mathrm{~d}$ in an $\mathrm{H}_{2}+\mathrm{CO}_{2}$ atmosphere in an anaerobic jar. The isolates able to multiply at $8^{\circ} \mathrm{C}$ were chosen for further examination.

The isolates chosen were examined from Gram reaction, general morphology, catalase production, anid presence of spores. The general key used for the identification was Bergey's Manual of Determinative Bacteriology $(11,19)$. The general morphological, physiological, and biochemical characteristics of the lactic acid bacteria isolates were determined according to Sharpe $(17,18)$. The carbohydrates tested were amygdalin, L-arabinose, cellobiose, lactose, maltose, D-mannitol, D-mannose, melibiose, melezitose, D-ribose, salicin, sucrose, and D-xylose. The production of ammonia from arginine was tested with the method of Briggs (3) using $2 \%$ glucose in the medium. The method of Gibson and Abdel-Malek (5) was used to test for the ability to produce gas from glucose. The tests used were chosen according to their ability to distinguish the lactic acid bacteria isolated from spoiled cooked ring sausages by Korkeala and Mäkelä (8).

\section{Computer analysis}

The isolates were analyzed by computer cluster analysis with a BAKT-ID program (Scientific Expert System, Helsinki, Finland) and compared to the profiles of lactic acid bacteria strains isolated from spoiled vacuum-packed cooked ring sausages by Korkeala and Mäkelä ( 8 ).

\section{RESULTS}

The mean aerobic plate counts and the mean lactic acid bacteria counts of the raw materials are shown in Table 1. The highest microbial counts were observed in the pork skin emulsion and the meat trimmings, in which the aerobic plate counts were between $1.0 \times 10^{4}$ and 1.6 $x 10^{8} \mathrm{CFU} / \mathrm{g}$. Lactic acid bacteria were frequently found in the pork skin emulsion, the meat trimmings, the skim milk powder, and the potato flour. The highest lactic acid bacteria count $\left(5.0 \times 10^{5} \mathrm{CFU} / \mathrm{g}\right)$ was observed in the beef trimmings. The commercial spice mixture had a mean aerobic plate count of $2.0 \times 10^{5} \mathrm{CFU} / \mathrm{g}$, but lactic acid bacteria over $100 \mathrm{CFU} / \mathrm{g}$ were found in only one of the samples studied.

Lactic acid bacteria isolates able to multiply at $8^{\circ} \mathrm{C}$ were found in the pork skin emulsion, the meat trimmings, the skim milk powder, and the potato flour (Table 2). The proportion of these isolates varied between 71 and $92 \%$ of the lactic acid bacteria isolates studied in each raw material category. The only isolate from the commercial spice mixture was unable to growth at $8^{\circ} \mathrm{C}$.

The 137 isolates capable of growth at $8^{\circ} \mathrm{C}$ were studied in greater detail. All these isolates were nonspore-

TABLE 1. Mean aerobic plate and lactic acid bacteria counts in the raw materials of cooked ring sausages.

\begin{tabular}{lccc}
\hline Raw materials & $\begin{array}{c}\text { No. of } \\
\text { samples }\end{array}$ & $\begin{array}{c}\text { Mean aerobic } \\
\text { plate count }^{1}\end{array}$ & $\begin{array}{c}\text { Mean lactic acid } \\
\text { bacteria count }\end{array}$ \\
\hline Pork skin emulsion & 10 & $6.3(5.0-8.2)$ & $4.4(<2.0-4.6)$ \\
Pork trimmings & 15 & $5.3(4.0-6.7)$ & $3.0(<2.0-4.6)$ \\
Beef trimmings & 15 & $5.5(4.3-7.0)$ & $3.6(2.0-5.7)$ \\
Spice mixture & 10 & $5.3(3.8-6.7)$ & $<2.0(<2.0-2.0)$ \\
Skim milk powder & 10 & $3.5(<2.0-6.0)$ & $2.6(<2.0-4.2)$ \\
Potato flour & 10 & $3.0(<2.0-4.2)$ & $2.0(<2.0-2.6)$ \\
\hline
\end{tabular}

${ }^{1}$ Mean log count (CFU/g) and range; populations of $<100 \mathrm{CFU}$ were assigned 50 for calculation.
TABLE 2. Number of lactic acid bacteria isolates able to grow at $8^{\circ} \mathrm{C}$ found in raw materials of cooked ring sausages.

\begin{tabular}{lcc}
\hline Raw materials & $\begin{array}{c}\text { No. of isolates } \\
\text { studied }\end{array}$ & $\begin{array}{c}\text { No. of isolates } \\
\text { growing at } 8^{\circ} \mathrm{C}\end{array}$ \\
\hline Pork skin emulsion & 31 & 27 \\
Pork trimmings & 34 & 29 \\
Beef trimmings & 87 & 70 \\
Spice mixture & 1 & 0 \\
Skim milk powder & 42 & 30 \\
Potato flour & 13 & 12 \\
\hline
\end{tabular}

forming, Gram positive, catalase negative bacteria, and they were classified as lactic acid bacteria. These isolates could be divided on the basis of their physiological and biochemical characteristics using cluster analysis, into 6 homofermentative groups and 5 heterofermentative groups (Table 3). All isolates of the homofermentative groups were rod-shaped, arginine negative bacteria. The heterofermentative group 7 consisted of three arginine negative rods. The other heterofermentative groups were cocci. The groups differed from each other in their pattern of sugar fermentations. Each group contained isolates from two or more ingredients, except for the homofermentative group 5 , consisting of a single isolate from the beef trimmings, and the heterofermentative group 9 consisting of 11 isolates from the beef trimmings. All the isolates from the skim milk powder belonged to the same group. The other ingredients included isolates belonging to several groups.

The distribution of the examined isolates among different ingredients and the number of isolates resembling the lactic acid bacteria groups of Korkeala and Mäkelä (8) isolated from spoiled vacuum-packed cooked ring sausages are shown in Table 4. Isolates resembling the groups of Korkeala and Mäkelä (8) were recovered from the pork skin emulsion, the meat trimmings, the milk powder, and the potato flour.

TABLE 3. Homofermentative and heterofermentative groups of lactic acid bacteria isolates derived from the raw materials of cooked ring sausages, and source of isolates in each group.

\begin{tabular}{|c|c|c|}
\hline Group & $\begin{array}{l}\text { No. of } \\
\text { isolates }\end{array}$ & Source of isolation \\
\hline \multicolumn{3}{|c|}{ Homofermentative } \\
\hline 1 & 5 & $\begin{array}{l}\text { pork skim emulsion, pork } \\
\text { trimmings, beef trimmings }\end{array}$ \\
\hline 2 & 10 & $\begin{array}{l}\text { pork skim emulsion, pork } \\
\text { trimmings, beef trimmings }\end{array}$ \\
\hline 3 & 7 & $\begin{array}{l}\text { pork skin emulsion, pork } \\
\text { trimmings, beef trimmings }\end{array}$ \\
\hline 4 & 2 & beef trimmings, potato flour \\
\hline 5 & 1 & beef trimmings \\
\hline 6 & 40 & $\begin{array}{l}\text { pork skin emulsion, pork } \\
\text { trimmings, beef trimmings, skim } \\
\text { milk powder, potato flour }\end{array}$ \\
\hline \multicolumn{3}{|c|}{ Heterofermentative } \\
\hline 7 & 3 & $\begin{array}{l}\text { pork skin emulsion, pork } \\
\text { trimmings, beef trimmings }\end{array}$ \\
\hline 8 & 13 & pork trimmings, beef trimmings \\
\hline 9 & 11 & beef trimmings \\
\hline 10 & 40 & $\begin{array}{l}\text { pork trimmings, beef trimmings, } \\
\text { potato flour }\end{array}$ \\
\hline 11 & 5 & pork trimmings, potato flour \\
\hline
\end{tabular}


The pork skin emulsion and the pork trimmings contained isolates resembling the homofermentative group 4 of Korkeala and Mäkelä (8), while the beef trimmings had isolates resembling their homofermentative group 2 . The skim milk powder contained isolates which could be identified as belonging to the small homofermentative group 5 of Korkeala and Mäkelä (8). Isolates resembling their heterofermentative group 9 were found from the pork skin emulsion, the pork and the beef trimmings, and the potato flour. The pork and the beef trimmings also contained isolates similar to their heterofermentative group 10 .

TABLE 4. Numbers of isolates from raw materials of cooked ring sausages resembling the lactic acid bacteria groups of Korkeala and Mäkelä (8), isolated from spoiled vacuum-packed cooked ring sausages.

\begin{tabular}{lcr}
\hline Raw materials & $\begin{array}{c}\text { No. of isolates } \\
\text { studied }\end{array}$ & $\begin{array}{c}\text { No. of isolates resembling } \\
\text { groups of Korkeala and } \\
\text { Mäkelä (1989) }\end{array}$ \\
\hline Pork skin emulsion & 25 & 7 Group $4: 1^{1}$ \\
Pork trimmings & 27 & 10 Group $9: 6$ \\
& & Group $4: 3$ \\
Beef trimmings & 50 & Group $9: 6$ \\
& & 12 Group $2: 3$ \\
Skim milk powder & 25 & Group 9: 8 \\
Potato flour & 10 & Group 10: 1 \\
\hline
\end{tabular}

'Number of isolates resembling each group of Korkeala and Mäkelä (8).

\section{DISCUSSION}

Of the ingredients of the cooked ring sausages, all the materials studied, except for the commercial spice mixture, contained lactic acid bacteria to such an extent that these raw materials could act as a source of lactic acid bacteria at a sausage processing plant. The highest microbial counts were observed in the pork skin emulsion and the meat trimmings. Since these raw materials are used most extensively in the production of sausages, they probably form the most important source of lactic acid bacteria. Psychrotrophic strains were common in the lactic acid bacteria population of the raw materials, indicating that the raw materials could also contain strains able to cause spoilage at chill temperatures.

The lactic acid bacteria isolates able to grow at $8^{\circ} \mathrm{C}$ included both homofermentative and heterofermentative bacteria. Most of the raw materials contained isolates falling into many different groups, indicating the heterogenity of the lactic acid bacteria population in each ingredient category. Only the isolates from the skim milk powder seemed to be entirely homogeneous. The isolates from the different raw materials could not be divided into separate groups according to their origin. Thus none of the raw materials seemed to have a distinct lactic acid bacteria population of its own.

Isolates resembling the lactic acid bacteria groups isolated from spoiled ring sausages by Korkeala and Mäkelä (8) were found in all the raw materials studied except for the spice mixture. The homofermentative lactic acid bacteria groups of Korkeala and Mäkelä (8) consisted of psychrotrophic lactobacilli, while the heterofermentative groups belonged mainly to genus Leuconostoc. The pork skin emulsion and the meat trimmings contained isolates resembling the two main homofermentative groups of Korkeala and Mäkelä (8). These two groups included strains isolated both from the surface layer and from the center of the sausages. Since the surface bacteria of the sausages have been shown to be responsible for the spoilage $(7,9)$, it is probable that these raw materials include lactic acid bacteria strains able to cause spoilage. The heterofermentative groups 9 and 10 of Korkeala and Mäkelä (8) also contained both surface and center strains. Isolates resembling these groups were found in the pork skin emulsion, the meat trimmings, and the potato flour.

The isolates from the skim milk powder resembled the small homofermentative group 5 of Korkeala and Mäkelä (8), which included only two strains, both isolated from the center of the sausages. Since the milk powder did not contain isolates similar to the surface strains, it seems that the lactic acid bacteria originating in the skim milk powder do not play an important role in the spoilage process of the sausages. It may be that these bacteria do not succeed in competition with the spoilage bacteria.

This study shows that lactic acid bacteria isolates resembling the strains previously isolated from spoiled vacuum-packed ring sausages may be found in the raw materials of the sausages. Bacterial isolates similar to the surface layer bacteria, which have been shown to be responsible for the spoilage, were recovered from the pork skin emulsion, the meat trimmings, and the potato flour. All of these ingredients may thus form a source of spoilage bacteria for the vacuum-packed cooked ring sausages at a sausage processing plant.

Because contamination of the surface of cooked ring sausages with lactic acid bacteria has been shown to occur during the chilling and packing following the cooking of the sausages (13), the spoilage lactic acid bacteria originating from the raw materials may also be found in the chill and packing rooms of the plant. The bacteria from the raw materials can be spread to rooms of the plant, hence they can be further transferred to other rooms via the air, the workers, or the equipment. The bacteria may also become part of the normal bacterial population of the plant.

\section{ACKNOWLEDGMENT}

Excellent technical assistance of Ms. Maarit Peltokorpi is gratefully appreciated. This work was supported by the Academy of Finland, the Finnish Veterinary Science Foundation, and the Technology Development Center of Finland.

\section{REFERENCES}

1. Allen, J. R., and E. M. Foster. 1960. Spoilage of vacuum-packed sliced processed meats during refrigerated storage. Food Res. 25:1925.

2. Blickstad, E., and G. Molin. 1983. The microbial flora of smoked pork loin and frankfurter sausage stored in different gas atmospheres at $4^{\circ} \mathrm{C}$. J. Appl. Bacteriol. 54:45-56. 
3. Briggs, M. 1953. The classification of lactobacilli by means of physiological tests. J. Gen. Microbiol. 9:234-248.

4. Crossley, E. L., and W. A. Johnson. 1942. Bacteriological aspects of the manufacture of spray-dried milk and whey powders, including some observations concerning moisture content and solubility. J. Dairy Res. 13:5-44.

5. Gibson, T., and Y. Abdel-Malek. 1945. The formation of carbon dioxide by lactic acid bacteria and Bacillus licheniformis and a cultural method of detecting the process. J. Dairy Res. 14:35-44.

6. Kitchell, A. G., and G. C. Ingram. 1967. A survey of a factory for the sources of lactobacilli characteristic of vacuum packed Wiltshire bacon. Proc. 13th European Meeting of Meat Research Workers. Rotterdam, B2.

7. Korkeala, H., and S. Lindroth. 1987. Differences in microbial growth in the surface layer and at the center of vacuum-packed cooked ring sausages. Int. J. Food Microbiol. 4:105-110.

8. Korkeala, H., and P. Mäkelä. 1989. Characterization of lactic acid bacteria isolated from vacuum-packed cooked ring sausages. Int. J. Food Microbiol. 9:33-44.

9. Korkeala, H., S. Lindroth, R. Ahvenainen, and T. Alanko. 1987. Interrelationship between microbial numbers and other parameters in the spoilage of vacuum-packed cooked ring sausages. Int. J. Food Microbiol. 5:311-321.

10. Korkeala, H., S. Lindroth, M. Suihko, A. Kuhmonen, and P. L. Penttilä. 1985. Microbiological and sensory quality changes in blood pancakes and cooked ring sausages during storage. Int. J. Food Microbiol. 2:279-292.
11. Krieg, N. L., and H. G. Holt. (ed.) 1984. Bergey's manual of systematic bacteriology. vol. 1. Williams \& Wilkins, Baltimore, USA.

12. Lörincz, F., and K. Incze. 1961. Angaben über die Grünverfärbung von Fleisch und Fleischerzeugnissen hervorrufenden Laktobazillen. Fleischwirthschaft 13:406-407.

13. Mäkelä, P., and H. Korkeala. 1987. Lactobacillus contamination of cooked ring sausages at sausage processing plants. Int. J. Food Microbiol. 5:323-330.

14. Mol, J. H. H., J. E. A. Hietbring, H. W. M. Mollen, and J. van Tinteren. 1971. Observations of the microflora of vacuum-packed sliced cooked meat products. J. Appl. Bacteriol. 34:377-397.

15. Nottingham, P. M. 1982. Microbiology of carcass meats. pp.13-65. In M. H. Brown (ed.), Meat microbiology. Applied Science Publishers, London.

16. Reuter, G. 1970. Untersuchungen zur mikroflora von vorverpackten, aufgeschnittenen Brüh- und Kochwürsten. (Investigations on microflora in prepacked sliced cooked sausages and sausages of bologna type). Arch. Lebensmittelhyg. 21:257-264.

17. Sharpe, M. E. 1962. Taxomony of the lactobacilli. Dairy Sci. Abstr. 24:109-118.

18. Sharpe, M. E. 1979. Identification of the lactic acid bacteria. pp. 233 259. In F. A. Skinner and D. W. Lovelock (ed.), Identification methods for microbiologists. Academic Press, London,

19. Sneath, P. H. A., N. S. Mair, M. E. Sharpe, and J. G. Holt. (ed.) 1986. Bergey's manual of systematic bacteriology, vol. 2. Williams \& Wilkins, Baltimore, USA.

20. Warmbrod, F., and L. Fry. 1966. Coliform and total bacterial counts in spices, seasonings, and condiments. J. Assoc. Off. Anal. Chem. 49:678-680. 